\title{
Postawy duchowieństwa katolickiego wobec systemu komunistycznego w województwie lódzkim w latach 1948-1956 Zarys problemu
}

Publikacja dotyczy szeroko rozumianego problemu postaw ${ }^{1}$ duchowieństwa wobec komunizmu w odniesieniu do ówczesnego woj. łódzkiego. Termin „,postawa" znajduje zastosowanie w wielu dyscyplinach naukowych. W artykule skoncentrowano się na aspekcie historyczno-politologicznym. W szczególności badano zachowania i postawy duchownych w okresie głębokiego stalinizmu w odniesieniu do ośrodków władzy państwowej, wydawanych dekretów, rozporządzeń. W Polsce Ludowej niski standard życia oraz system awansów i wynagrodzeń zniechęcał do rzetelnej i uczciwej pracy i promował postawy konformistyczne i adaptacyjne. Zjawiska te dotyczyły wszystkich grup społecznych. Niestety uległa tym negatywnym zjawiskom trudna do określenia część duchownych $^{2}$. W opinii ówczesnych elit politycznych związanych z aparatem władzy po 1944 r. duchowieństwo postrzegane było jako najbardziej niebezpieczny przeciwnik systemu. Trzeba przyznać, że duchowni byli jedyną grupą społeczeństwa

${ }^{1}$ Termin ,postawa” wprowadzony został przez badaczy W. Thomasa i F. Znanieckiego we wstępie do Polish Teasant in Europe and America przede wszystkim w celu oznaczenia procesów indywidualnej świadomości, determinujących zarówno aktualne, jak potencjalne reakcje każdej osoby wobec społecznego świata. Postawa jest zawsze postawą wobec jakiejś wartości. Więcej na ten temat: W.J. Th o m a s, F. Z n a n i e c k i, Polish Teasant in Europe and America, t. I, Boston 1918-1920, s. 21. Cf. M. M o r a d y, Sens teoretyczny a sens empiryczny pojęcia postawy. Analiza metodologiczna zasad doboru wskaźników w badaniach nad postawami, Warszawa 1976; i d e m, Język propagandy i typy jego odbioru, Warszawa 1984.

${ }^{2} \mathrm{~W}$ tej materii badawczej istnieje pokaźna literatura. Oto tylko niektóre pozycje: J. W i a t r, Socjologia polityki, Warszawa 1999, s. 12, 19 i n.; S. N o w a k, Teorie postaw, Warszawa 1973, s. 23-33; E. Wnuk-Lipiński, Socjologia życia publicznego, Warszawa 2008, s. 11-12; B. W o j c i s z k e, Człowiek wśród ludzi. Zarys psychologii społecznej, Warszawa 1992, s. 123211 (omówiono tu m.in. postawy i wartości oraz czynniki wywierające wpływ na innych ludzi); D. B u s s, Psychologia ewolucyjna. Jak wyttumaczyć spoleczne zachowania człowieka, Gdańsk 2003, s. 281-305; W. W o s iń s k a, Psychologia życia spotecznego, Gdańsk 2004, s. 211-250. 
traktowaną jako „figurant zbiorowy”. W szczególności księża stali się obiektem rozpracowywania przez służby specjalne $\mathrm{z}$ tytułu przynależności do stanu duchownego ${ }^{3}$. Stąd od początku zdobycia władzy komuniści zwalczali Kościół środkami politycznymi, a z czasem karno-administracyjnymi. Jednocześnie duchowni wykazujący postawy obojętne, bierne czy niezdecydowane poddawani byli różnorodnym procesom i próbom tzw. lojalizacji ideowo-politycznej w kierunku współpracy z władzami państwowymi. W pierwszych latach po wojnie (1945-1947) władzę w kurii łódzkiej sprawował bp Włodzimierz Jasiński. Wykazywał zdecydowaną niechęć i wrogość wobec Polski Ludowej ${ }^{4}$.

Od listopada 1948 r. elastyczne postępowanie wobec władz państwowych prymasa Augusta Hlonda kontynuował jego następca, biskup lubelski Stefan Wyszyński. Początki kierowania przez niego Kościołem w Polsce zbiegły się z kongresem zjednoczeniowym, kiedy powstała Polska Zjednoczona Partia Robotnicza (PZPR). Wygłaszane tam zapowiedzi partyjnych przywódców jednoznacznie zapowiadały wytwarzanie podziałów wśród duchowieństwa i wiernych na część patriotyczną i reakcyjną w stosunku do „władzy ludowej”. Pierwszą należało organizować, wzmacniać i ustawicznie popierać. Natomiast drugą zwalczać, kompromitować i likwidować, aż do rozbicia wewnętrznej struktury Kościoła. W lipcu 1949 r. wzmogła się działalność aparatu władzy (zwłaszcza bezpieczeństwa) w zakresie inwigilacji i rozpracowywania operacyjnego w szeregach duchownych. Działania dezintegracyjne w Kościele katolickim miał osobiście wspierać Józef Stalin. Podczas rozmowy w Moskwie 1 sierpnia 1949 r. z Bolesławem Bierutem Stalin sugerował podjęcie działań, które miały skutecznie prowadzić do rozłamu w szeregach duchownych. Jak wówczas miał powiedzieć: „prawa karne potrzebne, ale nie one rozstrzygają"5. W Moskwie zaakceptował

${ }^{3}$ Cf. M. Z a r e m b a, Komunizm, legitymizacja, nacjonalizm, Warszawa 2005; J. S z a c k i, Historia myśli socjologicznej, Warszawa 2008; J. K a r p iń s k i, Polska - komunizm - opozycja. Słownik, Warszawa 1988, s. 137; J. Ż a r y n, Kościót a władza w Polsce (1945-1950), Warszawa 1997.

${ }^{4} C f$. F. M u s i a 1, „Kupczenie uczuciami”. Metody werbunku duchownych w pierwszej dekadzie PRL-u, [w:] i d e m, Raj grabarzy narodu. Studia i materiaty do dziejów aparatu represji w Polsce Ludowej 1945-1989, Kraków 2010, s. 156-163; J. S z c z e p a n i a k, Jak werbowano wspótpracownika (informator agentów) spośród duchownych, [w:] Kościót katolicki w czasach komunistycznej dyktatury. Między bohaterstwem a agentura, red. idem, M. Lasota, Kraków 2010, Studia i Materiały - Wydział Historii i Dziedzictwa Kulturowego Uniwersytetu Papieskiego Jana Pawła II w Krakowie, t. III, s. 57-60.

Biskup Włodzimierz Jasiński (1873-1965) - biskup diecezji łódzkiej w latach 1934-1946. Cf. http://pl.wikipedia.orgwiki/WlodzimierzJasinski (dostęp: 6 VI 2016). Władzom państwowym nie udało się go skłonić do prorządowych akcji społeczno-politycznych. Zapewne pod wpływem deklaracji episkopatu podpisał apel sztokholmski. Pod koniec 1946 r. bp Jasiński wycofał się z czynnego udziału w kierowaniu diecezją i zamieszkał w klasztorze.

${ }^{5}$ Cyt. za: Bierut u Stalina, „Polityka”, nr 18, 1 V1993. 
przygotowany, a wydany 5 sierpnia 19409 r. dekret o „ochronie wolności sumienia i wyznania”. Sankcje karne groziły tym księżom, którzy „nadużywają wolności sumienia i wyznania” i ,odmawiają obrzędu lub czynności religijnych z powodu działalności lub poglądów politycznych"”. W rzeczywistości dekret został wykorzystany przeciwko religijnemu wychowaniu w szkołach, ponieważ to kolidowało z prowadzoną polityką w zakresie laicyzmu i ateizmu. Zdawano sobie sprawę, że dekret spotka się z negatywną oceną hierarchów Kościoła. Dlatego zdecydowano się poprzedzić jego wydanie działaniami w zakresie koedukacji i profilaktyki. Przeprowadzone rozmowy z księżmi miały odpowiednio „zmiękczyć” i uelastycznić ich stanowisko oraz ich postawy ideowo-polityczne. Przede wszystkim usiłowano wysondować istotną dla władz kwestię: jaką postawę zajmie niższe duchowieństwo wobec ustroju, dekretu i państwa w ogóle. Decyzję o rozmowach utrzymywano w tajemnicy ze względu na ewentualne kontakty z księżmi. Z tego powodu na 7 sierpnia 1949 r. we wszystkich urzędach wojewódzkich zwołane zostały odprawy ze starostami w sprawie przeprowadzenia rozmów ${ }^{8}$. W woj. łódzkim miało być $15 \%$ księży pozytywnych, $20 \%$ niezdecydowanych, 35\% obojętnych, a 30\% nie udało się sklasyfikować ${ }^{9}$. Ci ostatni na ogół byli niezdecydowani, bojaźliwi i strachliwi. Niewątpliwie większość duchowieństwa łódzkiego wykazywała postawy wrogie, niezdecydowane i obojętne. Podane oficjalnie dane statystyczne należy traktować z dużym sceptycyzmem, jako materiał źródłowy wytworzony przez aparat partyjno-rządowy. Nie musiały do końca odzwierciedlać rzeczywistych nastrojów i postaw duchownych. Tym bardziej że tzw. rozmowy odbywały się w obecności funkcjonariuszy Urzędu Bezpieczeństwa (UB), co zapewne mogło wpływać na prezentowane postawy duchownych $^{10}$. Tak zwany postępowy kler miał być dla władz państwowych sojuszniczym partnerem, w praktyce czynnie uczestniczyć w finalizacji komunistycznej wersji porozumienia z Kościołem. Deklarowane w rozmowach pozy-

${ }^{6}$ Cf. H. D o m i n i c z a k, Organy bezpieczeństwa PRL w walce z Kościołem katolickim 1944 1990 w świetle dokumentów MSW, Warszawa 2000, s. 14-18; A. D u d e k, Państwo i Kościót w Polsce 1945-1970, Kraków 1995, s. 9-17; „Trybuna Ludu” z sierpnia 1949 r. (wszystkie numery); J. Ż a r y n, Kościót a władza w Polsce...; R. G r y z, Państwo a Kościół w Polsce 1945-1956. Na przykładzie województwa kieleckiego, Kraków 1999, s. 184.

${ }^{7}$ Cf. „Dziennik Ustaw” 1949, nr 45, poz. 334. Cf. „Kurier Codzienny”, 27 VIII 1949.

${ }^{8}$ Protokół z akcji zaznajamiania proboszczów z dekretem z 5 sierpnia 1949 r., Archiwum Akt Nowych [dalej: AAN], Ministerstwo Administracji Publicznej [dalej: MAP], sygn. 959 S, k. 56-64.

${ }^{9}$ Sprawozdanie z rozmów z księżmi w woj. łódzkim z 10 VIII 1949 r., AAN, MAP, sygn. 959 T, k. 54-65.

${ }^{10}$ Problematykę tę porusza wielu badaczy z obszaru politologii i historii metodologii. $C f$. niektóre tylko pozycje: J. S i e le z i n, Badania źródłoznawcze w politologii. Wybrane zagadnienia metodologiczne, Wrocław 2010; K. Narojczyk, Warsztat badawczy historyka w dobie rewolucji informatycznej, [w:] Wstęp do badań historycznych. Nauki pomocnicze historii i archiwistyka w systemie ksztatcenia studentów historii szkoły wyższej, red. M. Szczurowski, Toruń 2002, s. 51-52. 
tywne w sumie postawy wobec dekretu i Polski Ludowej można uznać za ukrytą formę konformizmu aktywnego. Niewykluczone, że w szeregach pozytywnych księży byli ci, którzy zachowywali postawy indyferentyzmu bądź oportunizmu.

Pod koniec 1949 r. rozpoczęła się kolejna akcja polityczna przeciwko „reakcyjnej części kleru”. Raporty UB notowały o znacznym wzroście pobożności i praktykach religijnych. Komuniści podjęli więc działania dezintegracyjne w szeregach duchownych. Wspomagały te działania nieliczne, ale hałaśliwe środowiska księży patriotów, wykazujące zachowania konformizmu aktywnego. W tym celu 12 września 1949 r. powstała m.in. tzw. Komisja Księży przy Związku Bojowników o Wolność i Demokrację (ZBoWiD). Komuniści usiłowali wykorzystać tych kapłanów do prowadzonej walki z episkopatem i „reakcyjnymi”" biskupami. Zaplanowano więc wspólnie niejako uderzyć w kościelną organizację Caritas, jednocześnie w fałszywym świetle ukazując jej dotychczasową działalność charytatywną. Aby uwiarygodnić konieczność działań UB, ukazywano opinii publicznej rzekome prowadzenie „antypaństwowych działań” i „nadużyć finansowych"11. Caritas został upaństwowiony i przejęty pod zarząd państwowy. W składzie nowego Caritasu znaleźli się przede wszystkim księża patrioci. Po likwidacji tej kościelnej organizacji władze państwowe podjęły działania w celu pozytywnego odebrania tego zdarzenia przez opinię publiczną. Dlatego 30 stycznia 1950 r. w Warszawie odbył się wiec z udziałem premiera Józefa Cyrankiewicza i wiceministra administracji publicznej Władysława Wolskiego. Manifestacja stała się politycznym widowiskiem mającym na celu dyskredytację episkopatu i „wrogich” księży. W prorządowych wystąpieniach „potępiono dotychczasowe władze Caritasu" 12 . W tym samym dniu w Krakowie biskupi zredagowali trzy dokumenty: pismo do prezydenta, list do duchowieństwa oraz oświadczenie do wiernych. Ten ostatni dokument księża mieli odczytać z ambon 12 lutego $1950 \mathrm{r}$. UB różnymi środkami próbowało nie dopuścić do jego wygłoszenia $\mathrm{w}$ parafiach $^{13}$.

Niezdecydowane stanowisko episkopatu w sprawach drugorzędnych urastało w przekonaniu władz państwowych do rangi priorytetowej. Wychwytywano te kontrowersyjne opinie, a następnie nagłaśniano w ówczesnych mediach. Oficjalne przekazy głosiły, jakoby istniały znaczne konflikty i podziały w szeregach

${ }^{11}$ Akcja „C” operacja przejęcia „Caritas” przez V Departament MBP 29-30 I 1950 r., Archiwum Prymasa Polski, Komisja Główna Episkopatu Polski 1946-1953. Cf. D. Z a m i a t a a, Caritas. Działalność i likwidacja organizacji 1945-1950, Lublin 2010; J. S t e f a n i a k, Zwiazek Bojowników o Wolność i Demokrację (ZBoWiD), [w:] Encyklopedia katolicka, Lublin 2014, t. XX, kol. 1511.

12 Działalność „Caritasu” w latach 1945-1949, Archiwum Konferencji Episkopatu Polski, sygn. 0220, k. 39. Cf. A. D re ch s 1 e r, Odpowiedzialni za miłość. Opolska Caritas w latach 1945-2005, Opole 2007.

${ }^{13}$ Cf. P. R a i n a, Kościót w PRL. Dokumenty, t. I, Poznań-Pelplin 1994-1996, s. 209. 
duchownych. Zbywano zaś milczeniem pozaprawne metody „pacyfikacji” Caritasu. Aby uwiarygodnić stanowisko władz, organizowano indywidualne rozmowy z wytypowanymi kapłanami. Dotyczyły one wysondowania prorządowych postaw i nastrojów. Usiłowano nakłonić niezdecydowanych duchownych do uczestnictwa w prorządowym Caritasie. Dnia 12 lutego $1951 \mathrm{r}$. odczytywany był list biskupów do wiernych. Napominano księży, ,aby nie wchodzili do »Caritasu«". W woj. łódzkim odbyło się 45 rozmów z księżmi, podczas których wytypowano 18 pozytywnych, którzy wyrazili zgodę na współpracę w państwowym Caritasie $^{14}$.

Przejęcie Caritasu stało się kolejnym etapem w walce z Kościołem katolickim. W następnych latach komuniści podejmowali próby w kierunku pozyskiwania dla systemu komunistycznego pozostałych duchownych, którzy wykazywali postawy wstrzemięźliwości, niezdecydowania czy bierności. Reżyserowane przez władze akcje pokojowe stawały się doskonałą okazją do takich działań.

W marcu 1950 r. Światowa Rada Pokoju uchwaliła programową odezwę skierowaną do wszystkich narodów świata. Wzywano w niej do przeprowadzenia ogólnoświatowego plebiscytu w sprawie zakazu broni atomowej. W dniu 17 kwietnia 1950 r. ukonstytuował się Polski Komitet Obrońców Pokoju (PKOP). W wydanej odezwie wzywano do składania podpisów pod apelem sztokholmskim. Akcję tę rozpoczął PKOP w kilka dni po podpisaniu tzw. porozumienia państwa z Kościołem (14 kwietnia 1950). Akcja ta od początku była sterowana przez ZSRR i kraje bloku wschodniego. W istocie zmierzano zdyskredytować w oczach opinii publicznej pakt wojskowy NATO i RFN. Nagłaśniano w ówczesnych mediach problematykę „walki o pokój”, a ogłoszony plebiscyt miał maskować ukryte cele polityki ZSRR i pokazywać, że to w tym kraju istniała prawdziwa demokracja i wolność. De facto świadomie podsycano emocje, aby wciągać jak najszersze kręgi społeczne w sterowaną odgórnie aktywność. W tym znaczeniu apel stał się wygodnym pretekstem do uderzenia w „reakcyjny kler” w celu jego ideowego zróżnicowania i podziałów. W składzie komitetów PKOP znaleźli się agitatorzy i propagatorzy ze środowiska księży patriotów ${ }^{15}$. Głoszone hasła walki o pokój stały się swoistym priorytetem i sloganem propagandowym ówczesnych władz państwowych. Odmowa złożenia podpisu była traktowana przez opinię publiczną jako akt wrogi wobec państwa. W woj. łódzkim bp Michał Klepacz ${ }^{16}$

${ }^{14}$ Informacja w sprawie Polski w Watykanie za I 1950 r., AAN, KC PZPR Sekretariat Kler katolicki 1949-1952, sygn. 237-V-156, k. 87-89.

${ }^{15}$ Cf. Z. Z i e 1 i ń s k i, Kościót w Polsce 1944-2002, Radom 2993, s. 84-94; J. S t e f a n i a k, Duchowieństwo polskie wobec Apelu Sztokholmskiego z roku 1950, „Teki Archiwalne” 2000, t. V (XXXVII), s. 43-57; Kwestionariusz w sprawie działalności agitacyjnej KOP w poszczególnych województwach (woj. łódzkie) z 4 V 1950 r., AAN, KC PZPR, sygn. 237-VIII-2659, k. 98-99.

${ }^{16}$ Biskup Michał Klepacz (1893-1967) - biskup diecezji łódzkiej w latach 1947-1967. Władze państwowe początkowo oceniały go niejednoznacznie. Z czasem strona rządowa podjęła dzia- 
„po namyśle” podpisał deklarację pokojową, a bp Kazimierz Tomczak ${ }^{17}$ uczynił to dopiero po wydaniu oświadczenia episkopatu. W Łodzi większość księży nie poparła tej akcji, natomiast w woj. łódzkim 462 księży diecezjalnych i 899 zakonnych zgodziła się podpisać deklaracje pokojowe. Z kolei 85 księży diecezjalnych i 125 zakonnych odmówiło podpisu ${ }^{18}$. W materiałach urzędu wyznaniowego są nieco inne dane statystyczne. Sprzeciw wobec akcji spisowej miało wyrazić 95 duchownych diecezjalnych i dziewięciu zakonnych. Ponadto aż 93 księży brało czynny udział w akcjach agitacyjnych. Negatywną postawę wobec spisu mieli wykazywać zwłaszcza księża katecheci ${ }^{19}$.

Komunistyczna propaganda na dwóch skrajnych biegunach sytuowała „reakcyjnych księży” i „księży patriotów”. Wypowiedzi tych ostatnich skrzętnie nagłaśniano i stawiano za wzór innym kapłanom. W założeniach strategicznych komunistów powszechna dezinformacja miała wywoływać negatywne nastawienie opinii publicznej do „reakcyjnego kleru” i hierarchii kościelnej. W konsekwencji

łania w kierunku bliższej współpracy. Wobec księży zachowywał dystans, rezerwę i bierność. Zabraniał księżom np. wypowiadania się na tematy polityczne (m.in. o projekcie nowej konstytucji). Nie zabraniał duchownym agitowania na rzecz akcji pokojowych. Osobiście podpisał apel sztokholmski i plebiscyt pokoju. Po aresztowaniu prymasa Wyszyńskiego uległ naciskom władz, przyjmując obowiązki przewodniczącego Konferencji Episkopatu Polski. Miał gruntowne wykształcenie humanistyczne, uznawany był „za dobrego dyplomatę”. Cechowała go ujmująca osobowość, był uśmiechnięty, serdeczny i kulturalny. Zaraz po nominacji na przewodniczącego KEP miał się udać na spotkanie z Bierutem i Cyrankiewiczem. Odmówił jednak „zaproszenia na kawę”. Więcej na ten temat: S. Gra d, Działalność bpa Michała Klepacza jako przewodniczacego KEP, „Łódzkie Studia Teologiczne” 1993, nr 2. Cf. http://pl.wikipedia.orgwiki/MichalKlepacz (dostęp: 6 VI 2016).

${ }^{17}$ Biskup Kazimierz Tomczak (1883-1967) - pierwszy łódzki biskup pomocniczy w latach 1927-1967. Środowiska katolickie uważały go za „największego teologa łódzkiego Kościoła”. W pierwszych latach Polski Ludowej był uważany ,za bardzo wrogiego biskupa”. Wykazywał zdecydowanie wrogie stanowisko do Polski Ludowej, ZSRR, rad narodowych i rządowych dekretów i rozporządzeń. Wyrażał też nieprzejednane wrogie stanowisko wobec działalności pozytywnych duchownych. Zdecydowanie krytykował decyzję władz państwowych o upaństwowieniu Caritasu. Referat wyznaniowy w swoich opiniach określał go nawet jako „wiernego sługę Watykanu”. Apel sztokholmski podpisał dopiero po oświadczeniu episkopatu. W 1953 r., z chwilą, kiedy bp Klepacz został przewodniczącym KEP, przyjął bardziej ostrożną i wyczekującą postawę. Zdaniem referatu wyznaniowego „stał się ostrożnym i ugodowym”. Za swoją wrogą postawę wobec władz został karnie usunięty z łódzkiej kurii. Więcej: Bp sufragan Tomczak Kazimierz, bp pomocniczy łódzki (Charakterystyka biskupa Tomczaka z 1956 r.), AAN, Urząd ds. Wyznań [dalej: UdsW], sygn. 125/266, k. 1-12. Cf. http://pl.wikipediaorgwiki/KazimierzTomczak (dostęp: 6 VI 2016).

${ }^{18}$ Notatka z 12 V i 22 XI 1950 r., AAN, KC PZPR Sekretariat Kler katolicki 1949-1952, sygn. 237-V-258, k. 67-69. Cf. Protokół z posiedzenia plenarnego KW PZPR w Łodzi z 18 V 1950 r., Archiwum Państwowe w Łodzi, KW PZPR, plena, sygn. 43-II-2, k. 23-25. Jak czytamy: „Akcja zbierania podpisów po d Apelem Sztokholmskim napotyka na wrogość kleru".

${ }^{19}$ Pismo prezydium WRN w Łodzi do UdsW w Warszawie z 19 IX 1950, AAN, UdsW, sygn. 5a/17A, k. 23-28. 
„dołowy kler" miał stracić zaufanie do reakcyjnej hierarchii kościelnej ${ }^{20}$. Postawa biskupów i księży była zróżnicowana. Niewykluczona manipulacja danymi liczbowymi odnośnie do udziału kapłanów w apelu sztokholmskim miała służyć doraźnym celom politycznym. Sprawozdania z przebiegu akcji spisowej na ogół sugerują „pozytywny przebieg akcji spisowej” i „dobrą współpracę z klerem”. Sporadycznie informowano o przypadkach ,wrogich postaw kleru”.

Kolejną akcją społeczną, do której usiłowano angażować duchownych, był Narodowy Plebiscyt Pokoju. Pod pozorem szlachetnych intencji kryły się doraźne cele polityczne i propagandowe. Tym manipulacjom psychotechnicznym uległa większość społeczeństwa, jak też trudna do ustalenia część księży i biskupów. Dnia 29 grudnia 1950 r. obradował w Warszawie episkopat, który zdecydowanie zadeklarował, że „biskupi nie powinni się zajmować działaniami o charakterze politycznym, gdyż to szkodzi i rozbija Kościół”. W szczególności dotyczyło to angażowania duchownych do różnego rodzaju akcji o charakterze agitacyjno-propagandowym. Oględność sformułowań może świadczyć, że obawiano się obecności konfidentów i współpracowników bezpieki ${ }^{21}$. Również władze państwowe podejmowały działania, które dotyczyły reedukacji duchownych, zwłaszcza tych o postawach niezdecydowanych, biernych i wstrzemięźliwych. Oficjalna propaganda publicznie nagłaśniała przypadki czynnego angażowania kapłanów na rzecz plebiscytu. Według oficjalnych przekazów źródłowych postawy duchownych w pierwszym etapie akcji spisowej uznawano za niezdecydowane i wyczekujące. Sporadycznie notowano przypadki „wrogich wystąpień księży"22. Dnia 30 kwietnia 1951 r. episkopat wydał stosowny komunikat, w którym oficjalnie nie zabraniano księżom udziału w plebiscycie pokoju. Natomiast kategorycznie zakazano uczestnictwa w akcjach propagandowych, agitacyjnych, trójkach spisowych itp.

W woj. łódzkim organizowane były spotkania duchowieństwa z uczestnikami Światowego Komitetu Obrońców Pokoju. Według zachowanych źródeł

${ }^{20} C f$. „Trybuna Ludu”, nr 164, 21 VII 1950. Tytuł prasowy z czołówki tego dziennika brzmiał: Katolicy polscy potępiaja stosunek episkopatu do Apelu Pokoju. Z kolei w „Trybunie Robotniczej” (z 19 VII 1950) pisano m.in. „Odrzucenie podpisów Apelu Sztokholmskiego prze episkopat oznacza, że biskupi kierują się interesami Watykanu". Cf. też: J. S t e f a n i a k, Prasa partyjna a prasa katolicka w latach 1945-1953, „Wiadomości Historyczne” 1998, nr 2, s. 70-78; M. Iło w i e c k i, Krzywe zwierciadło. O manipulacji w mediach, Lublin 2003, s. 66-69 (o kształtowaniu opinii publicznej).

${ }^{21}$ Informacje dotyczące kleru (29 XII 1950), AAN, KC PZPR Kler katolicki 1945-1952, sygn. 237-V-158, k. 23-28.

${ }^{22}$ Zjazdy, konferencje, odprawy, Sprawozdanie za I kwartał 1951 (13-14 IV 1951), AAN, UdsW, sygn. 7/2, k. 32-33. Cf. Uchwały Biura Politycznego 1949-1952, AAN, KC PZPR, sygn. 237-V-1, k. 65-67 (uchwały za I kwartał 1951). Cf. Prasa polska jest orężem walki o socjalizm i pokój, „Trybuna Ludu”, nr 6, 6 V 1951; Prasa w narodowym froncie walki o pokój i plan 6 letni, „Trybuna Ludu”, nr 129, 10 V 1951. 
w Piotrkowie w spotkaniach tych miało uczestniczyć 35 duchownych. Słabszą frekwencję, bo tylko ośmiu księży, zanotowano w Sieradzu i Wieluniu, zapewne z powodu zakazu ordynariusza łódzkiego ${ }^{23}$.

Relacje i sprawozdania organów państwowych z pierwszego etapu plebiscytu nie były zadowalające. Z powodu „małej aktywności” duchownych podjęto działania zaradcze. Dnia 19 kwietnia 1951 r. odbyło się w prezydium Wojewódzkiej Rady Narodowej (WRN) w Lodzi specjalna narada poświęcona „biernym postawom duchownych". Podczas zebrania straszono księży sankcjami administracyjnymi (np. domiarami podatkowymi, zakazem przydziału materiałów budowlanych). Podczas następnej konferencji roboczej 11 maja 1951 r. wysuwano ostre oskarżenia przeciwko Stolicy Apostolskiej, używając propagandowych haseł, jak „Watykan zionie nienawiścią do ZSRR”. Zdaniem obecnych aktywistów partyjno-rządowych niektórzy księża mieli „utracić zaufanie do Polski Ludowej”. W związku z tym podjęto stosowne zalecenia i zadania dla referatu wyznaniowego. Przede wszystkim nakazano wzywać duchownych na koedukacyjne pogadanki, nauki na tematy ideowo-polityczne. Podczas obligatoryjnych „rozmów” w referatach wyznaniowych uświadamiano „opornych” i „wrogich” duchownych m.in. o „roli Watykanu jak narzędzia w rękach imperializmu amerykańskiego”. Poza tym podejmowano próby „wciągania” duchownych do czynnego udziału w organizowaniu akcji pokojowych i plebiscytowych. W przypadku oporu i bojkotu przewidywane były sankcje o charakterze karno-administracyjnym ${ }^{24}$.

W dniu 15 maja 1951 r. w Łodzi odbyła się wojewódzka konferencja poświęcona akcji plebiscytowej. Wzięło w niej udział 65 duchownych. W powołanej wówczas tzw. Wojewódzkiej Komisji Plebiscytowej znalazło się 12 zakonników i 55 siostry zakonne. W dyskusji z udziałem ośmiu duchownych jeden z nich powiedział, że: „Sprawa pokoju to nie tylko sprawa polityczna, lecz narodu”,25. W wydanej rezolucji wszystkich księży zobowiązano do czynnego udziału w walce o pokój. W efekcie tych działań agitacyjno-propagandowych karty plebiscytowe w woj. łódzkim miało podpisać aż 95,3\% duchownych. Z kolei postawa kurii archidiecezjalnej diametralnie odbiegała od „powszechnego poparcia” plebiscytu przez ogół duchownych. Biskup Klepacz w ogóle nie zdecydował się przyjąć trójek spisowych, a bp Tomczak zapowiedział, że nie podpisze plebiscytu pokoju. I w tym przypadku należy z dużą ostrożnością przyjmować zachowane dane

${ }^{23}$ Sprawozdanie z działalności referatu ds. Wyznań za 1951, Sprawozdanie z odbytego spotkania w Łodzi z uczestnikami II Światowego KOP (5 I 1951), AAN, UdsW, sygn. 7/4, k. 87.

${ }^{24}$ Zjazdy, konferencje, odprawy. Protokół z odprawy z kierownikami referatów wyznaniowych w woj. łódzkim z 19 IV 1951, AAN, UdsW, sygn. 7/2, k. 24-34. Cf. Narodowy Plebiscyt Pokoju w Lodzi, raport za 16 V 1951, Centralne Archiwum Ministerstwa Spraw Wewnętrznych [dalej: CA MSWiA], Ministerstwo Bezpieczeństwa Publicznego (MBP), sygn. 564, k. 32.

${ }^{25}$ Cyt. za: Głosy czytelników, „Dziennik Łódzki” 1952, nr 38. 
w źródłach proweniencji państwowej ${ }^{26}$. Mimo że według oficjalnych danych większość duchownych miała podpisać karty plebiscytowe, to czyniła to w formie „milczącej aprobaty”. Księża na ogół zachowywali wstrzemięźliwość, bierność i dystans. Trudno zaś odnieść się do wiarygodności materiałów źródłowych, w kontekście deklarowanych motywacji postaw i intencji duchownych. W przeciwieństwie do apelu sztokholmskiego w dokumentacji plebiscytu pomijane były szczegółowe dane o wynikach i przebiegu akcji spisowej.

W 1951 r. kryteria klasyfikacji księży pod kątem ideowo-politycznym zostały uzupełnione o ich stosunek do Narodowej Pożyczki Rozwoju Sił Polski. Ogłoszona oficjalnie w czerwcu 1951 r. miała charakter przymusowy i zakładała wyemitowanie obligacji na sumę 1,6 mld zł, które miałyby być spłacone sukcesywnie w ciągu 20 lat bez oprocentowania. Co ciekawe, nie zanotowano żadnych widocznych przejawów protestów, co świadczyłoby o znacznym ubezwłasnowolnieniu całego społeczeństwa ${ }^{27}$. Zaletą tej operacji, w rzeczywistości będącej podwyżką cen, miało być zniesienie systemu kartkowego. Również na duchowieństwo nałożony został podatek w formie subskrypcji Narodowej Pożyczki Sił Polski. Dnia 19 czerwca 1951 r. episkopat wydał komunikat, który w świetle wydanej instrukcji wzywał duchowieństwo do osobistego i licznego udziału w subskrypcji. Władze państwowe wywierały na biskupów określone naciski, aby angażowali duchownych do tej kolejnej akcji politycznej. Z inspiracji biskupów duchowni z ambon rozpoczęli agitowanie dzieła pożyczki. Działania hierarchów w dużym stopniu wpływały mobilizująco na społeczeństwo i duchownych. Poza tym prasa partyjno-rządowa rozpoczęła szeroko zakrojoną kampanię agitacyjno-propagandową na swoich łamach. Również prasa religijno-dewocyjna agitowała na rzecz pożyczki ${ }^{28}$. Należy zaznaczyć, że na podstawie zachowanych źródeł archiwalnych odnoszących się do woj. łódzkiego żaden duchowny podczas kazań nie wspomniał o pożyczce. Podczas odprawy z kierownikami referatów wyznaniowych w Pruszkowie, w obecności przedstawicieli Urzędu ds. Wyznań (UdsW) i Komitetu Wojewódzkiego PZPR, wyrażono ubolewanie odnośnie do pasywnej i biernej postawy duchownych. Z kolei księża mieli powoływać się na „brak pozwolenia łódzkiej kurii” w sprawie pożyczki. Dlatego też zainteresowanie subskrypcją w szeregach duchownych było znikome. Księża mieli przekazy-

\footnotetext{
${ }^{26}$ Konferencja księży w woj. łódzkim. Pismo prezydium WRN w Łodzi do UdsW w Warszawie z 1 VI 1951 r., AAN, UdsW, sygn. 8/65, k. 98.

${ }^{27}$ D. J a r o s z, M. P a s z t o r, W krzywym zwierciadle. Polityka władz komunistycznych $w$ Polsce $w$ świetle pogłosek z lat 1949-1956, Warszawa 1995, s. 25. Cf. A. G a r li c k i, Stalinizm, Warszawa 1993, s. 42.

${ }^{28}$ AAN, UdsW, sygn. 19/535, k. 15. Cf. Listy Pasterskie Episkopatu Polski 1945-1974, „Editions du Dialogue” [Paris] 1975, list z 19 VI 1951 r., s. 56-57; „Słowo Powszechne”, nr 170, 21 VI 1951; Chcemy pokoju, „Salwator” 1951, nr 6; „Homo Dei” 1951, nr 2-3.
} 
wać małe kwoty na rzecz pożyczki, jak też unikać wszelkich kontaktów w tej sprawie z władzami lokalnymi ${ }^{29}$.

Władze państwowe usiłowały wykorzystać duchownych do działań agitacyjno-propagandowych w sprawie niepopularnych, ale obowiązkowych powinności wobec państwa. Należała do nich realizacja zadań dostaw obowiązkowych, akcji skupowych. Oczekiwano zwłaszcza, aby księża przypominali, a nawet nakłaniali wiernych (rolników) do wypełniania obowiązków wobec państwa. W woj. łódzkim, podobnie jak w całym kraju, duchowieństwo wykazywało zaś bierność wobec tych akcji. W przekonaniu referatu wyznaniowego duchowni, którzy aktywnie angażowali się po stronie władz, narażeni byli na szykany ze strony łódzkiej kurii. Ogólnie duchowni wykazywali postawy biernej opozycji. Dotyczyło to również akcji gospodarczych. Jedynie w kilku powiatach zanotowano sporadyczne przypadki udziału księży w skupie zboża.

Niewątpliwie znaczący wpływ na poczynania duchownych miała postawa kurii biskupiej w Lodzi $^{30}$. Na początku 1951 r. nasilił się ostry, represyjny w istocie atak na Kościół. W styczniu 1951 r. zostali usunięci administratorzy apostolscy z diecezji na Ziemiach Zachodnich. Na ich miejsce kapituły wybrały wikariuszy kapitulnych (księża patrioci). Dnia 27 stycznia 1952 r. władze ogłosiły projekt nowej konstytucji, a 17 lutego 1952 r. episkopat na ręce Bieruta złożył katolickie postulaty konstytucyjne. Biskupów najbardziej bulwersowała „zasada rozdziału Kościoła od państwa”. To właśnie pozytywni księża przewidywani byli jako rządowy partner władz państwowych, mający zastąpić „reakcyjną część episkopatu". Taki jednostronny przekaz medialny był kierowany w stronę społeczeństwa.

W całym kraju odbywały się liczne debaty i masówki w sprawie nowej konstytucji ${ }^{31}$. Strona rządowa usilnie zabiegała o poparcie przez duchowieństwo tego projektu. Pomoc niezwłocznie zadeklarowali księża patrioci. W dniu 14 lutego 1952 r. w Warszawie odbył się Zjazd Komisji Księży przy ZBoWiD. Uczestniczyło w nim 300 duchownych, jak również ówczesny szef UdsW Antoni Bida. Usiłowano wyciszyć wszelkie krytyczne opinie o projekcie nowej konstytu-

${ }^{29}$ Sprawozdanie kwartalne z działalności referatu wyznaniowego w Łodzi za 1951 r. Pismo prezydium WRN w Łodzi do UdsW w Warszawie z 5 VII 1951 r., AAN, UdsW, sygn. 7/5, k. 256. $C f$. Protokół z odprawy kierowników referatów wyznaniowych w Pruszkowie z 10 VII 1951 r., AAN, UdsW, sygn. 7/2, k. 34-35.

${ }^{30}$ Sprawozdanie referatu wyznaniowego w Łodzi. Pismo prezydium WRN w Łodzi do UdsW w Warszawie z 21 I 1951 r., AAN, UdsW, sygn. 7/5, k. 98-99. Cf. Zjazdy, konferencje, odprawy. Protokół z odprawy referatu wyznaniowego w Łodzi z 6 VIII 1951 r., AAN, UdsW, sygn. 7/2, k. 67-69.

${ }^{31}$ Pismo episkopatu do prezydenta z 11 II 1952 r. w związku z ogłoszeniem 27 I 1952 r. projektu nowej konstytucji, AAN, KC PZPR Sekretariat Kler katolicki 1949-1953, sygn. 237-V-166, k. $87-89$. 
$\mathrm{cji}^{32}$. Strona rządowa próbowała zmusić duchownych do poparcia projektu ustawy zasadniczej. W tej sprawie w prezydiach WRN przeprowadzono rozmowy z księżmi. Jednakże wzywani duchowni zachowywali dużą czujność, wstrzemięźliwość unikając jakichkolwiek wiążących i krytycznych wypowiedzi. Podczas jednej z odpraw kierowników referatów wyznaniowych w Łodzi 5 lutego 1952 r. wiodącymi tematami stały się kwestie związane $\mathrm{z}$,pprowadzeniem walki z reakcyjnym klerem”, jak też „szybsza budowa socjalizmu w Polsce”. W podjętej rezolucji wyrażono czynne poparcie dla projektu konstytucji. Deklarowano jednocześnie, że księża „o ile będą lojalni nie będzie grozić im niebezpieczeństwo" ${ }^{33}$. Pracownicy referatów wyznaniowych w woj. łódzkim mieli dokonać przeglądu nastrojów i postaw duchownych wobec projektu konstytucji. W każdej parafii mieli być wytypowani pozytywni kapłani ${ }^{34}$. W tym celu w prezydium WRN w Łodzi organizowano specjalne spotkania z udziałem duchownych. Podczas rozmów zapewniano ich o istnieniu wolności i swobodzie wypowiedzi. Na użytek propagandy stwarzano wrażenie, jakoby księża mogli mówić wszystko bez skrępowania. W praktyce każda wypowiedź duchownego była odnotowywana w specjalnie opracowanych kartotekach.

Wyrażana deklaracja ideowo-polityczna stawała się podstawą do kwalifikacji oceny duchownego. Negatywna postawa (wypowiedź) czy adnotacja o „wrogości" wobec ustroju i władz państwowych przesądzała niekiedy o losach duchownego na całe życie. Na przykład podczas rozmów w prezydium WRN w Łodzi stosowano socjotechniczne naciski (prowokacje słowne), w konsekwencji niektórzy kapłani wyrażali takie opinie: „Słusznie państwo pozwala dyskutować nad projektem konstytucji”. Zdarzały się jednak odważne wypowiedzi księży: „Konstytucja dla mnie mało ważna, gdyż jest to sprawa nie dla nas księży”, „Człowiek jest zależny od góry" ${ }^{35}$. Według oficjalnych przekazów źródłowych księża „na żywo" interesowali się projektem konstytucji. De facto jednak na ogół konsekwentnie zajmowali postawy wyczekujące, bierne i wstrzemięźliwe. Unikali ponadto szczerych i merytorycznych wypowiedzi. Być może na te pasywne po-

${ }^{32}$ Raport z 10 II-6 III 1952 r., Biuro Ewidencji i Archiwum [dalej: BEiA], Urząd Ochrony Państwa [dalej: UOP], sygn. V-14-41-3, k. 95-106. Cf. T. M a z o w i e c k i, Zagadnienia ustrojowe i społeczno-gospodarcze w projekcie konstytucji, „Słowo Powszechne” 1952, nr 21.

${ }^{33}$ Cyt. za: J. Ż a r y n, Dzieje Kościoła katolickiego w Polsce (1944-1989), Warszawa 2003, s. 151 .

${ }^{34}$ Protokół z odprawy roboczej w prezydium WRN w Łodzi z 5 II 1952 r., AAN, UdsW, sygn. 11/7, k. 7. $C f$. Rozmowy z księżmi w woj. łódzkim w sprawie projektu nowej konstytucji. Pismo prezydium WRN w Łodzi do UdsW w Warszawie z 20 II 1952 r., AAN, UdsW, sygn. 18/286, k. 65-67; Dyskusja w WRN w Łodzi nad projektem konstytucji, „Dziennik Łódzki” 1952, nr 38.

${ }^{35}$ Rozmowy z księżmi na temat projektu konstytucji w woj. łódzkim, AAN, UdsW, sygn. 18/286, k. 4-6. Cf. M. Ił o w i e c k i, Media, władza, świadomość społeczna, Łódź 1999; M. K a r w a t, Sztuka manipulacji politycznej, Torun 1999; Bp A. Le p a, Świat manipulacji, Częstochowa 1995. 
stawy wpływ mieli hierarchowie Kościoła. Poproszony o zajęcie głosu w tej sprawie bp Klepacz, na jednej z odpraw dekanalnych kategorycznie zabronił księżom wypowiadania się na temat konstytucji. Stąd zapewne na jednej z sesji WRN w Łodzi spośród obecnych kilkudziesięciu duchownych tylko jeden z nich odważył się zabrać głos. I tutaj dominowały postawy minorowe i bierne ${ }^{36}$. Prowadzona kampania propagandowa nad projektem nowej konstytucji stała się $\mathrm{w}$ istocie kolejnym pretekstem do ataków na reakcyjny kler i hierarchię kościelną. Tylko księża patrioci wspomagali tę odgórnie prowadzoną akcję polityczną. Szeregowe duchowieństwo w większości unikało włączania się w odgórnie sterowaną aktywność. Co ciekawe, Stalin miał wprowadzić ok. 50 poprawek w zapisach konstytucji, z czego 14 wprowadzono w preambule ${ }^{37}$.

Dnia 26 października 1952 r. w atmosferze strachu i terroru odbyły się wybory do Sejmu. Były one całkowicie zmanipulowane przez aparat bezpieczeństwa. Powszechne wyniki głosowania nie są znane. Formalnie 99,8\% miało poprzeć listę Frontu Narodowego, które skupiało de facto członków PZPR, ZSL i SD ${ }^{38}$. W Łodzi, podczas odprawy z kierownikami referatów wyznaniowych, postanowiono, że wobec księży należy stosować politykę liberalną, a unikać kar administracyjnych. Akcja propagandowa przed wyborami miała się stać sprawdzianem „prawdziwych postaw duchowieństwa wobec państwa ludowego”. Po wyborach zamierzano dokonać „politycznego rozpracowania” duchowieństwa. Przekazy źródłowe referatu wyznaniowego sugerują, że kler reakcyjny w woj. łódzkim miał stosować „wyrafinowane metody walki”. Jednocześnie wskazywano na znaczną liczbę księży pozytywnych, którzy mobilizowali wiernych do udziału w wyborach ${ }^{39}$. Przeważająca część duchownych zachowywała postawy biernej opozycji. Wyrażały się one w postawach nonkonformistycznych, a nawet oportunistycznych.

Ślubowanie „na wierność PRL” miało mieć charakter zbiorowy, a odbyło się 17 grudnia $1953 \mathrm{r}$ i dotyczyło tylko biskupów. Wcześniej jednak, bo już w kwietniu 1953 r., ślubowanie składały pierwsze grupy księży. W pierwszej kolejności

${ }^{36}$ Sprawozdanie Wydziału WRN w Łodzi za II kwartał 1952 r., AAN, KC PZPR Wydział Propagandy i Agitacji, sygn. 237-VIII-154, k. 12.

${ }^{37}$ Cf. A. G a r li c k i, Z tajnych archiwów, Warszawa 1993; J. Z a k r ze w s k a, M. R y b i c k i, Geneza i przygotowanie konstytucji PRL z 1952 roku, „Dzieje Najnowsze” 1984, R. XVI, z. 4, s. 91-116; Konstytucja PRL tarcza i orężem w walce o rozkwit i świetność naszej Ojczyzny, „Gromada - Rolnik Polski”, 27 VII 1952. Z kolei Leon Chajn, działacz SD, twierdził, że Stalin miał wprowadzić 82 poprawek do projektu konstytucji. $C f$. L. C h a j n, Kiedy Lublin byt Warszawa, Warszawa 1964, s. 20.

${ }^{38}$ Cf. Aparat bezpieczeństwa w Polsce w latach 1950-1952. Taktyka, strategia, metody, oprac. A. Dudek, A. Paczkowski, Warszawa 2000, s. 261.

${ }^{39}$ Protokół z odprawy referatu ds. Wyznań w Łodzi z 28 VIII 1952 r., AAN, UdsW, sygn. 11/23, k. 46-48. Cf. Wypowiedzi księży w woj. łódzkim dotyczące wyborów do Sejmu IX-X 1952, AAN, UdsW, sygn. 11/26, k. 4-6. 
wzywano do niego księży pozytywnie nastawionych do władz państwowych. Wywołało to zrozumiałe zaniepokojenie pozostałych kapłanów. Urzędy wyznaniowe przeprowadziły tę akcję w kilku etapach, aby wywoływać konflikty w środowiskach duchownych (bierni, wrodzy, niezdecydowani) ${ }^{40}$. Biskupi składali ślubowanie m.in. w obecności premiera J. Cyrankiewicza, wypowiadając słowa: „Uczynię wszystko dla rozwoju Polski Rzeczypospolitej Ludowej oraz umocnienia Jej siły i bezpieczeństwa"41. Wypowiadana formuła musiała być dla wielu kapłanów upokarzająca ${ }^{42}$.

Ślubowanie na ,wierność PRL” nie przypadkiem zbiegło się z dramatycznymi wydarzeniami. Po licznych procesach pokazowych (np. bpa Kaczmarka, księży z kurii krakowskiej) 28 września 1953 r., więc trzy dni po uwięzieniu prymasa Wyszyńskiego, bp Michał Klepacz przejął na żądanie władz stanowisko przewodniczącego Konferencji Episkopatu Polski ${ }^{43}$. Pod koniec 1953 r. episkopat powoli tracił kontakt z podległymi diecezjami. Rządy nad diecezjami i parafiami coraz częściej sprawowały prezydia WRN, referaty wyznaniowe i instancje bezpieczeństwa.

W woj. łódzkim ślubowano w pięciu grupach. Na wykazanych 345 księży aktu tego dopełniło 356. Jedenastu duchownych nie uczyniło tego z powodu negatywnej opinii wystawionej przez urząd wyznaniowy. Z kolei w czerwcu 1953 r. w trzeciej grupie nie ślubowało dziewięciu duchownych z powodu niedopuszczenia do ślubowania (,wrogi stosunek do władz”). Byli wśród nich m.in. kanclerz

${ }^{40}$ Cf. A. D u d e k, R. G r y z, Komuniści i Kościót w Polsce (1945-1989), Kraków 2003, s. 82; J. Ż a r y n, Dzieje Kościoła katolickiego ..., s. 134-137; A. D u d e k, Państwo i Kościół..., s. 75-79.

${ }^{41}$ Cyt. za: J. S t e f a n i a k, Dylematy księży. Dzwonić czy nie dzwonić? , „Przegląd Powszechny" 2003, nr 3, s. 356.

${ }^{42}$ J. Ż a r y n, Dzieje Kościoła katolickiego..., s. 151. Cf. Spuścizna A. Bidy, Informacja Polski w Watykanie 1952-1953, AAN, UdsW, sygn. 484/12, k. 5 (Ślubowanie duchowieństwa i Episkopatu Polski); Lista ordynariuszy i sufraganów zaproszonych do ślubowania 17 XII 1953 r., AAN, UdsW, sygn. 37/1790, k. 87-89 (43 uczestników).

${ }^{43}$ Od tego czasu bp Klepacz wykazywał tendencje w kierunku bliższego „prowadzenia dialogu” z władzami i „budowania mostów pojednania”. Skłonność do ugodowości i współpracy została „zauważona” przez organy bezpieczeństwa. Niewątpliwie nie służyło to interesom Kościoła. Oznaki słabości i uległości prezentowane przez niektórych hierarchów ułatwiały komunistom prowadzenie antykościelnej polityki. Przejawiała się ona w działaniach „konfliktowania” i „podsycania” negatywnych nastrojów i postaw w szeregach duchownych. Biskup Klepacz, który wykazywał postawy uległości wobec władz państwowych, naraził się na liczne zarzuty, zarówno ze strony duchownych, jak i wiernych. Niektóre wygłaszane opinie zawierały wręcz stwierdzenie, że miał być „komunistycznym hierarchą". Zastanawiać może okoliczność, że mimo osamotnienia w wielu przypadkach niezrozumienia bp Klepacz zdawał się wierzyć w słuszność obranej drogi i postawy. Polityka „układania” pozytywnych stosunków z lokalnymi władzami spotkała się jednak z krytyką ze strony niektórych członków Episkopatu. Cf. M. P r z y b y s z, Aparat bezpieczeństwa wobec kurii biskupiej w Łodzi w latach 1945-1967, [w:] Aparat bezpieczeństwa wobec kurii biskupich w Polsce, red. A. Dziurok, Warszawa 2009, s. 155-180. 
kurii i dwóch dziekanów. Do czerwca 1956 r. ślubowało dodatkowo 28 kapłanów, a pięciu nie przybyło z powodu choroby. Ogólnie akcję ślubowania władze uznały „,za sprawnie przeprowadzoną”. Jednakże podczas uroczystości ślubowania panował na ogół nastrój milczenia, smutku i powagi. Zanotowano, że przeważały postawy wyczekiwania, dystansu wobec władz państwowych ${ }^{44}$.

Stronę rządową niepokoiło to, że księży pozytywnych było stosunkowo za mało do pełnej realizacji zamierzonych wobec Kościoła działań. Z tego powodu planowana wymiana ogółu wrogich księży nie została zrealizowana. W pierwszym kwartale 1954 r. znaczną aktywność wykazywali księża patrioci i intelektualiści katoliccy. Oficjalne media jednostronnie informowały o ich wzorowych wobec państwa postawach. Natomiast postawy pozostałych duchownych ukazywano w niekorzystnym świetle. Tymczasem działania organów władzy zmierzające do wciągania duchownych $\mathrm{w}$ procesy społeczno-gospodarcze napotykały z ich strony na opór i trudności. Podobne trudności napotykali „intelektualiści katoliccy ze strony kurii i „reakcyjnych księży” ${ }^{45}$. Po uwięzieniu prymasa działalność propagandowo-agitacyjna tych „radykalnych” środowisk uległa nasileniu. Naprzeciw tym tendencjom wychodziły instancje partyjno-rządowe. W czerwcu 1954 r. urząd wyznaniowy z Ministerstwem Bezpieczeństwa Publicznego zainicjował program, który zakładał radykalne zmiany personalne w parafiach, dekanatach i kuriach diecezjalnych. $\mathrm{W}$ istocie to w wojewódzkich urzędach bezpieczeństwa rozstrzygał się proces decyzyjny w sprawach personalnych. Plan ten miał obejmować wymianę wszystkich księży uznawanych za wrogich. Projektowany zmiany personalne $\mathrm{w}$ placówkach kościelnych stwarzały niebezpieczeństwo ubezwłasnowolnienia Kościoła interesom państwa.

W woj. łódzkim niepokój urzędu wyznaniowego budziła „wroga postawa” alumnów i znacznej części kadry nauczającej (np. w Wieluniu). Analogicznie negatywnie oceniano postawę ideowo-polityczną władz w seminarium duchownym w Łodzi. Większość kadry profesorskiej (jak też jego rektor) mieli wykazywać postawy wrogie, bierne i obojętne. $Z$ kolei alumni seminarium wykazywali „dużą pobożność” i „bogate życie religijne”. Wrogą postawę miał wykazywać kanclerz łódzkiej kurii. Również księża zakonni w różnych zgromadzeniach i zakonach przejawiali postawy wrogie i obojętne. Na przykład w zakonie orionistów w Zduńskiej Woli stwierdzono dziewięciu „obojętnych”. Negatywne postawy i nastroje wyrażali też salezjanie w Grojnie k. Kutna, gdzie miało być czterech „wrogich” i jeden „obojętny”. Stawiano zarzuty kurii archidiecezjalnej

${ }^{44} C f$. Akcja ślubowania w woj. łódzkim. Pismo prezydium WRN w Łodzi do UdsW w Warszawie z 23 V 1953 r., AAN, UdsW, sygn. 84/122, k. 260-263; Pismo prezydium WRN w Łodzi do UdsW w Warszawie z 27 VI 1956 r., AAN, UdsW, sygn. 47/255, k. 324.

${ }^{45}$ Sprawozdanie $\mathrm{z}$ posiedzenia KIiDK w Łodzi. Pismo prezydium WRN w Łodzi do UdsW w Warszawie z 13 II 1954 r., AAN, UdsW, sygn. 44/1727, k. 78-79. 
w Łodzi, że nie zgadzała się na obsadzanie „patriotami” w wielu parafiach. Łódzki urząd wyznaniowy zalecił, aby nasilić kontrolę w seminariach duchownych i zakonach. Poza tym miały zostać przeprowadzone rozmowy z księżmi w kierunku ich skuteczniejszej lojalizacji i większej aktywności w akcjach społeczno-gospodarczych. Efekty tych działań okazały się mało skuteczne. W większości parafii łódzkich władzom lokalnym nie udało się obsadzić stanowisk przez księży patriotów ${ }^{46}$. Po wydaniu dekretu lutowego w 1953 r. i ślubowaniu księży i biskupów „na wierność PRL” nastąpił okres najgłębszego upolitycznienia Kościoła. Przede wszystkim odnosiło się to do ingerencji władz w sprawy obsady stanowisk kościelnych.

Od XX zjazdu Komunistycznej Partii Związku Radzieckiego, kiedy jej sekretarz Nikita Chruszczow ujawnił niektóre zbrodnie Stalina, system polityczny w Polsce wchodził w okres głębokiego kryzysu politycznego i gospodarczego. W ZSRR doszło do częściowej liberalizacji w życiu społeczno-politycznym, tzw. odwilży ${ }^{47}$. Okres ożywionej dyskusji związanej z upowszechnieniem się referatu Chruszczowa zbiegł się $\mathrm{z}$ tajemniczą śmiercią w Moskwie Bolesława Bieruta. Jego zgon 12 marca 1956 r. zamknął niewątpliwie w PRL epokę tzw. stalinizmu. Władze bezpieczeństwa skupiały uwagę na reakcjach duchownych. $\mathrm{Ci}$ ostatni najczęściej podawali w wątpliwość naturalną śmierć Bieruta. W propagandzie szeptanej mówiło się o uczuciach bólu ludności, masowych i samorzutnych wyjazdach do Warszawy na jego pogrzeb. Strona rządowa nie zamierzała tolerować aktywności duchownych. Przyznano jednak, że we wszystkich kościołach biły dzwony. Nie wykluczano, że mogło to być wynikiem wywieranych presji o charakterze administracyjnym. W woj. łódzkim tylko jeden $\mathrm{z}$ duchownych, mimo zakazu dziekana, dzwonów nie uruchomił. Stwierdzono również kilka przypadków wywieszania flag narodowych, składania listów kondolencyjnych. Oto tylko niektóre wrogie wypowiedzi duchownych: „Władze państwowe popełniły błąd nie podając komunikatów o chorobie Bieruta”, „Bierut już ostatnio nie odpowiadał obecnej linii polityki i musiał umrzeć”, „Jako posłuszny wykonawca zaleceń

${ }^{46}$ Pismo prezydium WRN w Łodzi do UdsW w Warszawie z 25 VII 1954 r., AAN, UdsW, sygn. 84/134, k. 136. W archidiecezji łódzkiej wśród wykazanych 79 duchownych miało być: 17 pozytywnych, 37 wrogich i dziewięciu nierozpoznanych. $C f$. Dane personalne i charakterystyka księży w woj. łódzkim w latach 1949-1956, AAN, UdsW, sygn. 84/97, k. 1-235. W Łodzi było 16 pozytywnych księży, 14 wrogich, 19 obojętnych i pięciu nierozpoznanych. $C f$. Dane personalne i charakterystyka księży w latach 1950-1955 (Miasto Łódź), AAN, UdsW, sygn. 84/98, k. 1-143. Z kolei według materiałów władz bezpieczeństwa stwierdzono 50 przypadków „wrogich wystąpień księży”, 19 „uprawiających wrogą propagandę” i 25 „występujących przeciwko ustawodawstwu PRL". $C f$. Zestawienie księży w archidiecezji łódzkiej, BEiA, UOP, sygn. 626/14, k. 1-106.

${ }^{47}$ Cf. K. K e r s t e n, Rok 1956 - Przełom? Kontynuacja? Punkt zwrotny?, [w:] Polska 1956 próba nowego spojrzenia, red. eadem, Warszawa 1997, s. 7-10. Termin „odwilż” pochodzi z tak zatytułowanej książki I. Erenburga, wydanej w 1955 r. Miał symbolizować proces topnienia stalinowskiego systemu, twardego jak lód. 
Stalina nie mógł osobiście naprawić tego co zrobił" ${ }^{48}$. Z kolei sporadyczne pozytywne wzmianki postaw księży mogły świadczyć, że duchowni wyrażali postawy wstrzemięźliwe, wyczekujące i pasywne. Zalecenia episkopatu o biciu w dzwony wielu księży odbierało jedynie jako przejaw posłuszeństwa wobec władz kościelnych. Deklarowane często pozytywne i przychylne postawy księży nie musiały być, i zapewne nie były, zgodne $\mathrm{z}$ wewnętrznymi przekonaniami i własnym sumieniem. Natomiast strona rządowa odbierała je jako wyraz pozytywnego nastawienia duchowieństwa do komunistycznego państwa. Rezygnacja z postaw otwarcie wrogich mogła świadczyć o rodzącym się zjawisku biernego oporu wśród duchowieństwa ${ }^{49}$.

Przesilenie polityczne w Polsce, jakie nastąpiło na początku 1956 r., spowodowało znaczny wzrost aktywności religijnej. Wzrosła świadomość narodowa i patriotyczna. VIII plenum Komitetu Centralnego PZPR (19-21 października 1950) wybrało Władysława Gomułkę na stanowisko I sekretarza. Gomułka obiecywał stabilizację i daleko posuniętą destalinizację kraju. Zapowiadał też zniesienie cenzury i polepszenie stosunków z Kościołem katolickim. Na mocy jego decyzji zwolniono m.in. z więzienia prymasa Stefana Wyszyńskiego. Zarówno poznański Czerwiec, jak i Październik zaskoczył wszystkich księży i wiernych. Zdawało się, że dawały jakąś nadzieję, iluzję, a niekiedy może poczucie optymizmu. W wydarzeniach lata i jesieni 1956 r. Kościół znalazł się jednak na marginesie wydarzeń. Ogół księży i hierarchów nie ugiął się dalszym naciskom i presji. Nie poszedł na żadną kolaborację czy współpracę z władzami komunistycznymi. Symbolem nieugiętości i heroizmu pozostawał zwłaszcza prymas Stefan Wyszyński. Częściowe złagodzenie polityki represyjnej, jak też częściowa liberalizacja polityki wobec Kościoła, wydarzenia Czerwca i Października nie spowodowały istotnego naruszenia podstawowych pryncypiów systemu komunistycznego. Dotyczyło to także wzajemnych relacji w stosunkach państwa z Kościołem.

Należy zaznaczyć, że zarysowany jedynie w zarysie problem badawczy wymaga pogłębionych studiów i badań. W szczególności dotyczy to kwestii szerszego dostępu do zasobów źródeł proweniencji kościelnej, dotychczas nie w pełni wykorzystanych. Rzecz dotyczy także niezbadanych jeszcze dostatecznie źródeł w zasobach służb specjalnych.

${ }^{48}$ Pismo prezydium WRN w Łodzi do UdsW w Warszawie z 22 III 1956 r., AAN, UdsW, sygn. 47/1580, k. 42.

${ }^{49} C f$. J. S t e f a n i a k, Dylematy księży..., s. 351-359. 


\section{Catholic clergy attitudes towards communist system Lodz Voivodeship from 1944 to 1956}

The present publication concerns Catholic clergy attitudes towards communist system in Lodz Voivodeship. From the very beginning of change of political system in 1944 members of clergy were submitted to various forms of forcing them to be politically loyal and ready to cooperate with the authorities. The undertaken research leads to a conclusion that the opinion promoted by contemporary propaganda presenting attitudes among the clergy as mostly positive does not seem to be so certain. In Lodz Diocese passive and moderate feelings certainly dominated, as well as those of awaiting. Not uncommon were disapproving or even hostile attitudes towards the new system, authorities, directives and decrees passed. Positive attitudes were rare. Year 1956 only partly restricted the repressive policy of the authorities towards the clergy. 